\title{
Flora of Singapore precursors, 20: Notes on the genus Piper (Piperaceae) from Singapore
}

\author{
P.R. Gajurel ${ }^{1} \&$ H.K. Lua ${ }^{2}$ \\ ${ }^{1}$ Department of Forestry, North Eastern Regional \\ Institute of Science \& Technology, \\ Nirjuli - 791109, Arunachal Pradesh, India \\ prgajurel@gmail.com \\ ${ }^{2}$ National Biodiversity Centre, National Parks Board, \\ 1 Cluny Road, 259569 Singapore
}

ABSTRACT. Nomenclatural notes on six species of Piper occurring in Singapore are provided. Nine names are typified. Additional relevant information on the species is also included.

Keywords. Distribution, lectotype, nomenclature, synonym, typification

\section{Introduction}

Piper L. is well known for species such as $P$. nigrum L., the pepper of commerce, $P$. longum L., the pipali of Ayurvedic medicine, P. betle L., the commercial betel leaf, and $P$. methysticum G.Forst., the medicinal kava. It is one of the largest genera of Angiosperms with about 2000 species (Quijano-Abril et al., 2006) distributed mostly in Neotropical and Paleotropical regions with the highest diversity in the Neotropics. About 600 species are reported from Asia with a major concentration in the Malesian region where there are about 450 species (Asmarayani, 2018). The taxonomy of the genus Piper from the region that is now Peninsular Malaysia and Singapore has been investigated by de Candolle (1869, 1912, 1914), Hooker (1886) and Ridley (1924). Hooker (1886) remarked that Piper is 'A most difficult genus, herbarium materials for the analysis of which have never been intelligently collected, whilst the descriptions of the published species are quite inadequate for their accurate determination'. Even almost one and a half centuries after his publication, the same is true. The dioecious nature of the species, the microscopic achlamydeous flowers, and the high intraspecific variation in the Asian species, makes the accurate delimitation of species difficult. Moreover, due to the recognition of a large number of species, particularly by de Candolle, without a thorough understanding of the ranges of variation in the species, clarifying the taxonomy has become increasingly challenging over time. Recently significant progress has been made on resolving taxonomic problems in Asia and a large number of species have been reduced to synonymy after careful typification and verification of species limits (Chew, 1992, 2003; Gilbert \& Xia, 1999; Gajurel, 2002; Suwanphakdee \& Chantaranothai, 2011; Suwanphakdee, 2012; Suwanphakdee et al., 2016, 2018; Mukherjee, 2017, 2018). However, not all problems were solved, particularly in the Malesian region, and considerably more work is still necessary. 
During our studies on the Piperaceae for the Flora of Singapore, we have had to solve a number of taxonomic problems for several Piper species based on a thorough study of the herbarium materials and through fieldwork. We have also found that many names have not yet been lectotypified. In this paper we lectotypify 10 names, now comprising six species, and discuss a number of other nomenclatural issues. One species is reduced to synonymy.

\section{Materials and methods}

The morphological characters and the range of variation within each of the species were studied from herbarium specimens and field work in Singapore. The original material for the names being considered was ascertained from the protologues. Images of the type material are available from many different herbaria through Global Plants on JSTOR (http://plants.jstor.org/), or studied at herbaria visited. Materials relevant for our study are mostly housed in HAL, G-DC, GZU, K, NYBG, P, PRC, U (for Herbarium codes see Thiers, continuously updated). The choice of designation of each lectotype is explained. Nomenclatural clarifications are given following Turland et al. (2018).

\section{Typifications}

1. Piper curtisii C.DC., Rec. Bot. Surv. India 6: 14 (1912); de Candolle, J. Asiat. Soc. Bengal 75: 318 (1914). - TYPE: [Peninsular Malaysia], Malacca, 1 October 1885, Alvins 2337 (lectotype SING [SING0206243], designated here).

Distribution. Peninsular Malaysia and Singapore.

Notes. Piper curtisii was described by de Candolle (1912) where he cited five collections from the Malay peninsula: Curtis 2699, from Perak, Waterloo, King's Collector 6263 from Perak, Larut, Scortechini s.n. from Perak, Curtis s.n, from Kuala Lumpur, Selangor and Alvins 2337 (but as Ridley 2337), from Malacca. From the five collections we have located four specimens: Curtis 2699 (K [K000794926]), Alvins 2337 (SING [SING0206243]), King's Collector 6263 (G-DC [G00314122]) and Scortechini s.n. (G-DC [G00314123]). We have chosen the specimen Alvins 2337 at SING as the lectotype.

2. Piper ramipilum C.DC., Rec. Bot. Surv. India 6: 3 (1912); de Candolle, J. Asiat. Soc. Bengal 75: 299 (1914). - TYPE: [Peninsular Malaysia], Penang, Balik Palau, March 1892, Curtis 792 (lectotype SING [SING0194877], designated here; isolectotypes K [K000794921, K000794922]). 
Distribution. Myanmar, Thailand, Peninsular Malaysia and Singapore.

Notes. Piper ramipilum was described by de Candolle (1912) based on seven collections from Penang, Perak and Johor in Peninsular Malaysia. He cited the collections Curtis 792, Kunstler 1481, Kunstler 270 and Deschamps s.n. from Penang, Ridley 9582 and King's collector 3574 from Perak, and Ridley 11022 from Johor. We have not found a specimen of Ridley 9582 from Gunong Keledang, Perak but have located the following materials: Curtis 792 (SING [SING0194877], K [K000794921, K000794922]), Kunstler 1481 (G-DC [G00322194]), Kunstler 270 (G-DC [G00322515]), Deschamps s.n. (G-DC [G00322209]), King's collector 3574 (NY [NY00283873]) and Ridley 11022 (K [K000794920]). We designate Curtis 792 (SING [SING0194877]) as the most representative specimen as lectotype.

3. Piper macropiper Pennant, Outlin. Globe 4: 242 (1800). - Piper arborescens Roxb., Hort. Bengal. 80 (1814). - TYPE: [Published illustration] Rumphius, Herb. Amboin. 5: t. 28, fig. 1 (1747).

Piper miniatum Blume, Verh. Batav. Genootsch. Kunst. 11: 166 (1826). - Chavica miniata (Blume) Miq., Syst. Piperac. 234 (1843). - TYPE: [Indonesia, West Java], Gunong Parang, s.d., Blume 1270 (lectotype G-DC [G00206627], designated here).

Piper glandulosum Opiz in Pres1, Reliq. Haenk. 1: 158 (1828). - Chavica glandulosa (Opiz) C.Presl, Epimel. Bot. 223 (1851). - TYPE: Philippines, Luzon, s.d., Haenke s.n. (lectotype PRC [PRC450581], designated here; isolectotypes HAL [HAL0101617], PRC [PRC450108]).

Distribution. India, Peninsular Malaysia, Singapore, Sumatra, Borneo, Java, Sulawesi, Moluccas, Philippines, New Guinea and Solomon Islands.

Notes. Piper miniatum has been treated as a distinct species by some authors (Keng, 1978, 1990; Turner, 1993) even though Merrill treated it as synonymous with $P$. arborescens (Merrill, 1917) and, later, P. macropiper (Merrill, 1948). Piper miniatum was described by Blume based on his own collections from Parang and Tjiradjas in Karawang in West Java, Indonesia. We have traced herbarium sheets from Parang (GDC [G00206627]) and from Tjiradjas (G-DC [G00206611, G00206628]), the latter with two specimens on the same sheet. We designate the specimen from Parang labelled as Blume 1270 (G-DC [G00206627]) as the lectotype as it is the better specimen.

Piper glandulosum was described from a Haenke collection from Luzon in the Philippines. We have located two specimens of Haenke s.n. at PRC and one specimen at HAL [HAL0101617]. One of the specimens at PRC is selected as the lectotype. De Candolle (1914) included the species under Piper miniatum and we confirm that it is conspecific with Piper macropiper. 
4. Piper maingayi Hook.f., Fl. Brit. India 5: 80 (1886). - TYPE: [Peninsular Malaysia], Malacca, April 1867, Maingay 1336 (lectotype K [K000575318], designated here; isolectotype G-DC [G00320526]).

Distribution. Peninsular Malaysia and Singapore.

Notes. This species was described by Hooker (1886) based on Maingay collections from Malaysia and Singapore. We have located three specimens of which two are at $\mathrm{K}$ (Maingay 1336 [K000575318] \& Maingay 1334/3086 [K000575319]) and one is at G-DC (Maingay 1336 [G00320526]). One of the specimens at K [K000575319] has both the Kew Distribution number of 1334 with a collection locality of Malaya and Maingay's collection number of 3086 with a collection locality of Singapore. Maingay 1336 [K000575318], a male plant, is the better specimen and is selected as lectotype.

5. Piper obtusissimum Miq., Syst. Piperac. 337 (1844). - Piper clypeatum Wall ex C.DC in A.DC., Prodr. 16(1): 378 (1869), nom. illeg. - TYPE: Singapore, 1822, Wallich $6655 B$ p.p. (lectotype GZU [GZU000256190], designated here).

Piper manillanum Miq., Syst. Piperac. 339 (1844). - TYPE: Singapore, 1822, Wallich $6655 B$ p.p. (lectotype GZU [GZU000256191], designated here).

Distribution. India, Peninsular Malaysia, Singapore and Philippines.

Notes. Piper obtusissimum and P. manillanum were described by Miquel (1844) in the same work. While describing these two species, Miquel included the invalid Wallich name Piper clypeatum and cited Wallich 6655B (in part) from Singapore for both species. Additionally, he also cited Gaudichaud s.n., March 1837 from Pulao Pinang, Malaya for P. obtusissimum and Gaudichaud 145, December 1836 from Manila, Philippines for P. manillanum. When the types cited by Miquel were examined, all specimens were found to belong to the same species with some morphological variations. Two of the specimens of Wallich $6655 \mathrm{~B}$ cited by Miquel are located at GZU [GZU000256190, GZU000256191], annotated as Piper obtusissimum and Piper manillanum respectively, both of which are leafy twigs only. These two Wallich specimens are quite different in leaf size which probably led Miquel to treat them as two different entities. Two Gaudichaud's specimens from Pulao Pinang are located at $\mathrm{P}$ [P02025653, P02025649] while one specimen from Manila is located at U [U1476337]. The Gaudichaud specimens from Pulao Pinang and Manila also look quite distinct from each other but are of the same species. The specimens of Piper manillanum from Manila (Gaudichaud 145 at U) and from Singapore (Wallich 6655B at GZU [GZU000256191]) have very small leaves while the specimens of $P$. obtusissimum from Pulao Pinang (Gaudichaud s.n. at GZU [GZU000256190] and P [P02025649, P02025653] ) have larger leaves. All of this material is of a single variable species for which the name Piper obtusissimum is chosen to have priority over $P$. manillanum as 
the type materials are more representative of the variation usually found in the species. We have selected the specimens of Wallich $6655 B$ at GZU as lectotypes for the two names.

Piper clypeatum was later described by de Candolle (1869), who took up Wallich's name and included the two Miquel species ( $P$. obtusissimum and $P$. manillanum) as synonyms. This made the name Piper clypeatum superfluous.

Piper obtusissimum is one of the most distinct species in the genus Piper and has never been recorded in its fertile state. The species can easily be recognised by the unique character of the overlapping leaves which are round or oval and adpressed with recurved margins to the surface of the tree bark or rock on which it is climbing. Its habit bears some similarity to some Pothos L. species in the Araceae. Hooker (1886) included the species in a list of "Indeterminable and Excluded Species" of Piper and believed it to be a species of Ficus. Unpublished DNA sequence data from Dr Matti Niissalo (Singapore Botanic Gardens) confirms that it is a Piper (based on ITS sequence data, GenBank no. MT844072 - voucher Lim et al. SING2019-023,16 Jan 2019 (SING)).

6. Piper schizonephros C.DC. in A.DC., Prodr. 16(1): 241 (1869). - Schizonephros glaucescens Griff., Not. P1. Asiat. 4: 383 (1854), as 'Schizonephos'. - TYPE: [Peninsular Malaysia], Malacca, Ching, Nhingull, 1845, Griffith s.n. (lectotype K [K000842201], designated here).

Piper polygynum C.DC., Rec. Bot. Surv. India 6: 27 (1912), syn. nov.; de Candolle, J. Asiat. Soc. Bengal 75: 337 (1914). - TYPE: [Peninsular Malaysia], Selangor, Gunong Pass, 1 May 1892, Wray 4068 (lectotype G-DC [G00322193], designated here).

Distribution. Peninsular Malaysia and Singapore.

Notes. Piper schizonephos was published by de Candolle (1869) on moving the species Schizonephos glaucescens Griffith (1854) into Piper sect. Schizonephos. He used the specific epithet 'schizonephos' as Piper glaucescens was not available for use. The word 'Schizonephos' as used by Griffith and de Candolle is an orthographic error which was later rectified by Hooker (1886) who stated "I have altered the misprint 'Schizonephos' to 'nephros' as in Griffith's mss." whilst clarifying that the derivation of the name is from the kidney-shaped (reniform) receptacle of the male spike.

The description of Schizonephros glaucescens was based on Griffith collections from Ching, Malacca. We have located four specimens believed to be original material of Schizonephros glaucescens, three specimens of Griffith 4400 at GH [GH00011479], $\mathrm{K}$ [K000575317] and P [P 01980783], none of which have locality details except "Burma \& Malaya Peninsula", and another specimen at K [K000842201] annotated as "Malacca Griffith 1845" as well as "Ching Nhingull" with reference to Griffith's protologue page no. 383. As this specimen has the precise locality information as cited by Griffith and is in good condition, it is selected as the lectotype. 
De Candolle described Piper polygynum based on the Malayan collections of Stephenson s.n. from Sungei Ugong, Penang and Wray 4068, from Gunong Pass, Selangor. On studying original material online and additional specimens at SING we found it to be conspecific with Piper schizonephros and have reduced it to synonymy. As we could not trace any material of Stephenson s.n. and located only Wray 4068 at $\mathrm{G}-\mathrm{DC}$, this specimen is selected as lectotype.

ACKNOWLEDGEMENTS. The authors thank Dr David Middleton, Singapore Botanic Gardens for his valuable inputs during preparation of the manuscript. We thank Dr Kanchi Gandhi, Harvard University for his comments for the clarification of some nomenclatural issues and Dr Matti Niissalo for his sequencing of and comments on Piper obtusissimum. The help and support of the staff of SING is duly acknowledged. The first author is thankful to the Director, NERIST for granting permission and leave to avail the Flora of Singapore Research Fellowship offered by the National Parks Board, Singapore in 2019.

\section{References}

Asmarayani, R. (2018). Phylogenetic study of Malesian-Pacific Piper (Piperaceae). Taxon 67: 693-724.

Chew, W.-L. (1992). Studies in Malesian Piperaceae II. Blumea 37: 159-164

Chew, W.-L. (2003). Studies in Malesian Piperaceae 3. Gard. Bull. Singapore 55: 13-25.

De Candolle, C. (1869). Piperaceae. In: de Candolle, A.P. (ed.) Prodromus Systematis Naturalis Regni Vegetabilis, vol. 16. Paris.

De Candolle, C. (1912). Piperaceae Novae e Peninsula Malayana. Rec. Bot. Surv. India 6(1): $1-27$.

De Candolle, C. (1914). Materials for a Flora of the Malayan Peninsula, no. 24, Piperaceae. $J$. Asiat. Soc. Bengal 75: 288-339.

Gajurel, P.R. (2002). Experimental taxonomic studies on Piper occurring in Arunachal Pradesh, India. PhD. thesis, North Eastern Hill University, India.

Gilbert, M.G. \& Xia, N.H. (1999). Notes on Piperaceae from China. Novon 9(2): 190-198.

Griffith, W. (1854). Notulae ad Plantas Asiaticas, pt. 4, Dicotyledonous plants. Calcutta: C.A.Serrao.

Hooker, J.D. (1886). Piperaceae. In: Hooker, J.D. (ed.) Flora of British India, vol. 5, pp. 78-99. London: L. Reeve \& Co.

Keng, H. (1978). Annotated list of Seed plants of Singapore (V). Gard. Bull. Singapore 31(2): 84-113.

Keng, H. (1990). The Concise Flora of Singapore, vol. 1, Gymnosperms and Dicotyledons. Singapore: Singapore University Press.

Merrill, E.D. (1917). An Interpretation of Rumphius's Herbarium Amboinense. Manila: Bureau of Science.

Merrill, E.D. (1948). An overlooked flora Indica. J. Arnold Arb. 29: 186-192.

Miquel, F.A.W. (1844). Systema Piperacearum. Roterdomi: H. A. Kramers.

Mukherjee, P.K. (2017). Nomenclatural notes on Piper Linn. (Piperaceae) from India. Phytotaxa 289(2): 188-192. 
Mukherjee, P.K. (2018). Nomenclatural notes on Piper L. (Piperaceae) from India II. Phytotaxa 338(1): 17-32.

Quijano-Abril, M.A., Callejas, R. \& Miranda-Esquivel, D.R. (2006). Areas of endemism and distribution patterns for Neotropical Piper species (Piperaceae). J. Biogeogr. 33: 12661278.

Ridley, H.N. (1924). Piperaceae. In: The Flora of the Malay Peninsula, vol. 3, pp. 25-51. London: L. Reeve \& Co.

Suwanphakdee, C. (2012). Systematics and Utilization of the Family Piperaceae in Thailand. $\mathrm{PhD}$ thesis, Khon Kaen University, Thailand.

Suwanphakdee, C. \& Chantaranothai, P. (2011). A new species and three taxonomic changes in Piper (Piperaceae) from Thailand. Blumea 56: 235-239.

Suwanphakdee, C., Simpson, D.A., Hodkinson, T.R. \& Chantaranothai, P. (2016). Taxonomic notes on the genus Piper (Piperaceae). Nordic J. Bot. 34: 605-618.

Suwanphakdee, C., Simpson, D.A., Hodkinson, T.R. \& Chantaranothai, P. (2018). Typification of Piper species (Piperaceae) in Southeast Asia, especially Thailand. Kew Bull. 73:33.

Thiers, B. (continuously updated). Index Herbariorum: A global directory of public herbaria and associated staff. New York Botanical Garden's Virtual Herbarium. http://sweetgum. nybg.org/science/ih. Accessed 6 Jul. 2020.

Turland, N.J., Wiersema, J.H., Barrie, F.R., Greuter, W., Hawksworth, D.L., Herendeen, P.S., Knapp, S., Kusber, W.-H., Li, D.-Z., Marhold, K. et al. (eds) (2018). International Code of Nomenclature for algae, fungi, and plants (Shenzhen Code) adopted by the Nineteenth International Botanical Congress Shenzhen, China, July 2017. Regnum Vegetabile 159. Glashütten: Koeltz Botanical Books.

Turner, I.M. (1993). The names used for Singapore plants since 1900. Gard. Bull. Singapore 45(1): 1-287. 
